The evidence then of the debris of vegetation and of the freshwater and land shells found with the Mammoths' remains, amply confirm the $a$ priori conclusion that the climate of Northern Siberia was at the epoch of the Mammoth much more temperate than now. It seems that the botanical facies of the district was not unlike that of Southern Siberia, that the larch, the willow, and the alnaster were probably the prevailing trees, that the limit of woods extended far to the north of its present range, and doubtless as far as the Arctic Sea; that not only the mean temperature was much higher, but it is probable that the winters were of a temperate and not of an aretic type, and roughly we may conjecture that Lithuania, where the bison still survives, and where so many of the other contemporaries of the Mammoth still live, probably presents to us a not unfaithful picture of what Northern Siberia must have been like from the Urals to Behrings Straits, and that it was probably in such a condition of things as prevails in Lithuania that the Siberian Mammoth thrived the best.

We have seen reason, therefore, to conclude that the Mammoth lived in all parts of Siberia where his remains are now found, and that when he lived there, a comparatively mild climate prevailed in Northern Asia to the very borders of the Arctic Sea. These are not the only nor the most important lessons which we can learn from the Mammoth remains of Siberia. Other conclusions of a more revolutionary and heterodox character seem to us to be inevitable corollaries from the facts. Before we venture to propound them, however, we must shortly examine the problem in other areas than Siberia, where Mammoth remains abound, i.e. in Europe and America, and to this we hope hereafter to devote another paper.

\title{
NOTICFS OF IMEIMOIRS.
}

I.-Cenni Sulla Geologia Della Gadita. Prof. A. Issel. Ann. del Mus. Civ. di St. Nat. di Genova, vol. xv., 1880, with coloured Map.

PROFESSOR ISSEL, who made one of the party in a cruise from Penoa to the north coast of Africa, in the cutter "Violante," belonging to and commanded by Capt. Henry Albertis, has already written an account of the voyage, and now adds a sketch of the geology of the Galita islands north of Tunis.

The largest island Galita is two miles and three-quarters long by one mile and a half broad. The higher parts of the islands are composed of granite, while a large portion of the island Galita is composed of travertine containing the remains of some indeterminable herbaceous plants and Helix vermiculata, Müll., $\boldsymbol{H}$. aspera, Müll., $H$. submeridionalis, B., $H$. amanda, Ross, $H$. trochoides, Boiret, II. Kabiliana, H. Berlieri, species of shells which Prof. Issel also now found living on the islands. This formation belongs to the Quateruary period, and probably after the Glacial period, and he supposes that the elevation of the island took place at the time of the great elevation which raised the marine bed of the African desert.

DECADE II.- 
In some parts of the coast, and especially along the southern shores, there is a marine Quaternary deposit showing a recent elevation of the island.

Bory de St.-Vincent, Renou, and Velain, are the only authors who have previously described the geology of these islands, and their opinions do not coincide. Bory de St.-Vincent spoke of the rocks of Galita as trachyte, and speaks of the islands being raised by volcanic agencies. Renou, on the other hand, described a grey granite as existing on the island Galita, with melaphyre or diorite at the extremities of the island, a large extension of black unfossiliferous calcareous rock which he considered of Jurassic age. Velain mentions eruptive rocks, and speaks of trachytes having much analogy with the andesites of the equator and the blue porphyries of L'Esterol.

Finding this difference of opinion concerning the crystalline rocks, Prof. Issel brought back a large series of specimens, and gave them a very careful macroscopical and microscopical examination, and also submitted some of them to Prof. Grattarola, who, after similar examination, confirmed Prof. Issel's opinion that it was a true granite, and said he had some specimens of Elban granite which could with difficulty be distinguished from it.

Prof. Issel considers that the difference of opinion arrived at by experienced geologists is because the granites of Galita sometimes assume the aspect of certain quartziferous trachytes, besides perhaps there is not an essential difference, and the characters by which granites are distinguished from the trachytes depends probubly on the different age, and the particular condition under which consolidation has taken place.

This group of islands is really a prolongation of the granitic mountains of Sardinia. The schists which had been described as Jurassic are thought to be of Silurian age, corresponding to some not far off in the north of Africa.

A. W. W.

II.-Jourmal of the Royal Microscopical Society. Vol. III. Nos. 1-5. February to October, 1880. With several Plates. 8vo. (Williams \& Norgate, London and Edinburgh.)

THIS Journal contains also the Transactions and Proceedings of the Society, and a record of current researches relating to Invertebrata, Cryptogamia, Microscopy, etc., including Embryology and Histology generally, and is edited, under the direction of the Publication Committee, by Frank Crisp, LL.B., B.A., F.L.S., one of the Secretaries of the Society, assisted by Messrs. A. W. Bennett, Prof. F. Jeffrey Bell, and S. O. Ridley, Fellows of the Society.

A special feature of the Journal is the Classified Record, which it contains, of the work of British and Foreign observers relating to the Invertebrata, Cryptogamia, etc., as appearing in more than 300 of the principal Journals and Transactions of this and other countries; notes and abstracts being furnished of the memoirs and papers, and arranged systematically. 
The bibliography, or list of titles, is also classified as follows: ZooLOGY.

A. General (including Embryology and Histology of the Vertebrata).

B. Invertebrata. - - Mollusca. Molluscoida. Arthropoda: (a) Insecta. ( $\beta$ ) Myriapoda. ( $\gamma)$ Arachnida. ( $\delta$ ) Crustacea. Vermes. Echinodermata. Coclenterata. Porifera. Protozoa. Botayy.

A. General (including Embryology and Histology of the Phanerogamia).

B. Cryptogamia. - Cryptogamia Vascularia. Muscineæ. Characeæ. Fungi. Lichenes. Algæ.

Mrckoscopr, etc.-Methods. Instrumental, etc.

The only exception to the completeness of the Bibliography (within the prescribed limits of the Invertebrata, Cryptogamia, etc.) is in regard to (1) the Insecta, only such articles being noted as are of general interest, lists and descriptions of new species, local faunæ, ete., being omitted; and (2) Palæontology, which is dealt with so far only as bearing on living forms or structural features; and, for the present, only a few of the principal Geological Journals, etc., are included.

Even within these limits many points of interest are brought within the notice of the English student and geologist, either of actual importance or suggestive of further inquiry. The biological notices are frequently of direct interest to the student of fossils, and of the life of a species.

In illustration of the geological contents of the biological record in this valuable bi-monthly Journal of the Royal Microscopical Society, we quote the following :-

"Aspidura."-Dr. Hans Pohlig gives a fresh definition of this interesting Triassic Ophiurid, from the Muschelkalk of Germany, which he divides into two subgenera, Amphiglypha and Hemiglypha, of which the former is broader and has shorter arm-spines than the latter; in each case a single species is alone known. He regards this form, which is the only Ophiurid as yet found in this stratum, as representing an extinet genus, which is distinguished from all its allies by the possession of larger, closely connected, radial shields, and by the bilateral groove on its oral shields; belonging to the Ophiolepidæ, it is intermediate in charaeter between Ophioglypha and Ophiopus. Hemiglypha has many points of resemblance to the Asterida, and appears to occupy a similar position among the Ophiurida to that held by Brisinga among the Asterida.

"It may be interesting to observe that Pohlig agrees with Haeckel in regarding the Asterida as the older forms."

1 Zeitsehr. wiss. Zool. vol. xxxi. (1878) p. 235. 


\section{III.-I Diaspri delta Toscana e i loro Fossili. Per Prof. Dante} Pantanklui. Mem. della Reale Accad. dei Lincei. Ser. 3, vol. viii. June, 1880.

DROF. DANTE PANTANELLI has presented a valuable memoir on the Jaspers of Tuscany, in which he has found, as mentioned in his preliminary announcement, a large number of Radiolaria. ${ }^{1}$

In the definition now given of the rock, it is said to be constituted of amorphous silica, together with crystallized silica, stained with metallic and earthy oxides, often distinctly crystallized in the mass of the silica. It contains the remains of organisms with siliceous skeletons, and occurs in clefts and in raised and stratified masses.

This "diaspro" is abundant in various horizons of the Upper Eocene of Tuscany, and is found in stratified layers which rarely exceed five centimetres between the hard masses of clay called galestro, and sometimes between incoherent material or strata of siliceo-calcareous rocks.

Professor Pantanelli describes thirty-two species of Radiolaria from the "diaspro," and says they are larger than their living allies, and after a criticism of the results of the Challenger and other expeditions, concludes that these deposits bave been formed in not less than one thousand mètres, for the number of Radiolaria is known to increase with the depth, while the number of Foraminifera on the other hand diminishes.

Geologists have maintained that the origin of diaspro was metamorphic, or at least the result of silicification posterior to deposition, until De Stefani a few years ago doubted the correctness of this idea, and it is now shown that the rock in question cannot be formed by metamorphism caused by the vicinity of igneous rocks for several reasons; among others, it could not attain such great thickness, nor as now shown contain fossils; nor is it only found in the Eocene, where metamorphic action might be attributed to the serpentine, but also in the Chalk and Lias, where no eruptive rocks are known; and further, in the Eocene the "diaspro" is often very far from any igneous rocks. Calcareous or sandy strata are sometimes intercalated in the galestro, and in the same way the serpentines are sometimes separated from the galestro by unaltered calcareous strata.

Professor Pantanelli considers that this compact rock is formed in much the same way as calcareous ones by analogous phenomena, the incoherent material in this case being agglntinated by the silica in solution in the acid water, so that the cracks, instead of being filled with calcite, as in the latter case, are full of quartz.

Stoppani, De Stefani, Bonney, Issel, have recently maintained that the serpentines represented true submarine lavas of the Upper Eocene, and this receives additional support, or rather proof, from the present discovery, and at the same time the presence of these fossils excludes the idea of the galestro and other of the series having a metamorphic origin. A. W. W.

1 See preliminary notice, Geou. Maa. 1880, July No. p. 317 . 
IV.-I Teróeni Sabbiosi e ra Fillosera. Boll. del R. Comit. Geol. d'Italia. July, August, 1880.

7 IEE Italian Minister of Agriculture communicated to the engineer of the mines at Caltanisetta in Sicily the observations of the French Society of Agriculture, relating to the soils in which the Phylloxera was most abundant. It appears that they noticed that the vines in argillaceous and compact soils fell a victim to the Phylloxera, whilst in sandy soils they were unaffected. The most favourable being soils with a large proportion of siliceous, and not above 12 per cent. of calcareous sand. It was found that, where the roots of vines passed through two strata, one sandy and the other argillaceous, the part of the root which traversed the argillaceous soil was covered with Phylloxera, whilst the rest passing through the sand was healthy, and not at all attacked by the insects.

In reply to this, Sig. P. Posi sends a very interesting report on the geology and culture of the vine in Sicily. Most are grown on volcanic soils, but all volcanic rocks are not suited for vine culture, as when it is vitreous nothing will grow, whereas felspathic lavas, rich in potash and easily subject to atmospheric decomposition, are eminently fitted for growing vines; but the most productive of all are the extensive deposits of fine ashes. Sig. Posi says that the rain of ashes during the last eruption added so much to the fertility of the soil that it much more than compensated for any damage done by the eruption to the forests and other cultivated land. He points out that the physical nature of these ashes approaches so much to that of loose sand that it may very possibly resist the invasion of the phylloxera, and thinks it worthy of further experiment, seeing that while it contains the necessary elements for the growth of the vine, there is no argillaceous material to favour the growth of the phylloxera. After the volcanic earths, most of the vine culture is in the Pliocene and Miocene sands, with but little in the marly districts.

\section{REVIEWS.}

I.-Annales de la Société Malacologique de Belgique. Tome

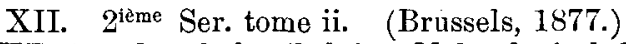

THE Annals of the Belgian Malacological Society for the year 1 1877, just issued, contains, in addition to geological and malocological papers and the bulletins of the Society, an exhaustive list of eight 8 vo. pages of titles of memoirs relating to living and fossil Brachiopoda. This useful and very complete bibliography was compiled with considerable labour and research by Mr. Thomas Davidson, F.R.S., the chief historian of the group, who, it is evident therefrom, has himself contributed since 1847 over fifty memoirs to the literature of the class. The list contains more than 1,200 alphabetical entries, from the earliest publications of the seventeenth and eighteenth centuries of Colonna (in 1606), Pallas, Rumphins, and Cuvier, up to the more recent works of Owen, Hancock, Huxley, King, Morse, Kovalevsky, etc., until the month of April, 1876. It was intended as an appendix to the French translation of the author's memoir, 